\title{
STUDI BIBLIKA SPRITUALITAS MANUSIA BARU \\ BERDASARKAN SURAT EFESUS 4: 23-32
}

\section{Tri Astuti}

(Dosen Tetap S2 Teologi STT Kristus Alfa Omega: triastuti1511@yahoo.com )

\begin{abstract}
The news of the New Testament can be summarized as; God wants us to be His children, in the image of His likeness. The problem is how can believer achieve the God's goal of becoming a new human being? In Ephesians 4: 23-32 Paul explains about how believer can have a true new human spirituality. The purpose of this research is to find out how believers can have true new human spirituality. The research method used is a qualitative biblical approach by using historical and grammatical analysis. The results found several important behaviors that need to be done by believers to experience the renewal of the quality of the spiritual mind, in order to grow into a new human being desired by God, that is, speaking according to the truth, controlling anger, working optimally and behaving affectionately.
\end{abstract}

Keywords: Spirituality, New Man, Ephesians, Renewal

\section{A. PENDAHULUAN}

Laporan dari kitab Kejadian, yaitu dalam kisah penciptaan mengungkapkan dengan jelas, bahwa Allah menciptakan manusia serupa dan segambar dengan diriNya. Apa yang telah dicipta Allah adalah sempurna tetapi kuasa dosa telah merusak semua yang baik dan yang sempurna itu. John Wesley lebih tegas mengatakan bahwa kejatuhan manusia ke dalam dosa mengakibatkan kerusakan secara total dalam keserupaan moral (moral image) dengan Allah. ${ }^{1}$ Pemulihan gambar Allah menjadi alasan mendasar, mengapa Allah masih terus berkarya ditengah-tengah umat kepunyaan-Nya sampai saat ini.

Donald Guthrie dalam sebuah tulisan mengatakan: "bila disederhanakan berita Perjanjian Baru dapat diringkas menjadi; Allah menginginkan kita menjadi anak-anakNya, dalam gambar keserupaan dengan Dia. Allah bertujuan membentuk kita sedemikian, sehingga menjadi mirip denganNya”. Pribadi manusia baru yang adalah keserupaan gambar Allah, merupakan fokus dari proyek penyelamatan Allah atas umatNya. Jadi perlu dipahami bahwa tujuan akhir dari proses penyelamatan Allah adalah pembentukan manusia baru atau pemulihan gambar Allah dalam pribadi umat. Millard J. Erickson berkata, bahwa karya Roh

${ }^{1}$ Richard M. Daulay, Mengenal Gereja Metodist Indonesia (Jakarta:BPK Gunung Mulia 2004)., 24. 
Kudus dalam diri orang percaya tidak hanya sampai pada menjadikannya sebagai orang percaya, tidak hanya sampai menerangi orang percaya namun menjadikannya manusia baru yang serupa dengan Allah. ${ }^{2}$ Pribadi manusia baru yang adalah keserupaan gambar Allah, merupakan fokus dari proyek penyelematan Allah atas umatNya.

Paulus sebagai tokoh penting dalam gereja purba, sering berbicara tentang topik manusia baru. Secara khusus kepada jemaat di Efesus, Paulus menasehati orang-orang di Efesus untuk meninggalkan kehidupan manusia lama, agar mereka dapat menjadi manusia baru (Efesus 4:23-32). Pada bagian sebelumnya, Paulus sudah menjelaskan bahwa orangorang percaya yang telah menerima Yesus dan ajaranNya, disebut ciptaan baru yang harus mengerjakan pekerjaan baik yang telah dipersiapkan oleh Allah (Ef. 2:10). Namun dalam Efesus 4:17-23, tampaknya Paulus membedakan antara ciptaan baru dengan manusia baru. Dalam Efesus 4:23-32 ini Paulus diduga memberikan kunci bagaimana orang percaya atau “ciptaan baru” memiliki spiritualitas manusia baru yang sejati. Jadi penelitian yang berjudul "Studi Biblika Spiritualitas Manusia Baru Menurut Surat Efesus", bertujuan untuk menemukan bagaimana sebenarnya perilaku spiritualitas manusia baru yang disebutkan Paulus, yang dapat menjadi penyebab pembaharuan "roh dan pikiran" atau kualitas pikiran rohani orang-orang percaya yang ada di Efesus. Lebih lanjut, hasil penelitian ini diperlukan supaya dapat diaplikasikan dalam kehidupan orang-orang percaya saat ini agar dapat mengalami pembaharuan kualitas rohani.

\section{B. METODOLOGY}

Metode yang digunakan dalam tulisan ini adalah menganalisis data kualitatif dengan pendekatan hermeneutik atau eksegese surat Efesus, untuk menemukan bahasan tentang spiritualitas manusia baru. Secara khusus penelitian menggunakan prinsip-prinsip eksegesa untuk mendekati teks, adapun di antaranya dilakukan analisa historika, analisa konteks, analisa syntax, analisa morfology, dan juga analisa leksikal pada teks. ${ }^{3}$ Terlebih dahulu dilakukan analisa historika, selanjutnya analisa konteks, dan analisa gramatika pada teks

\footnotetext{
${ }^{2}$ Donald Guthrie, Tafsiran Alkitab Masa Kini (Jakarta: Komunikasi Bina Kasih, 2001), 862.

${ }^{3}$ Gidion, "Memahami Pekerjaan Roh Kudus Dalam Pelayanan Gereja Berdasarkan 1 Dan 2 Timotius," HARVESTER: Jurnal Teologi dan Kepemimpinan Kristen 4, no. 2 (2019): $108-121$.
} 
Efesus 4:23-32. Setelah dilakukan analisa tersebut, maka selanjutnya dianalisa terkait ciri-ciri spiritualitas manusia baru yang dibicarakan si penulis kitab/surat.

\section{PEMBAHASAN}

\section{Eksposisi Efesus 4:23-24}

Dalam ayat sebelumnya, Paulus memberikan penegasan atas perintah untuk menanggalkan pola hidup "manusia lama", yang dalam ayat 17 disebut sebagai pola hidup “orang yang tidak mengenal Allah". Pada ayat 23-24 Paulus berkata: "supaya kamu dibaharui di dalam roh dan pikiranmu, dan mengenakan manusia baru yang telah diciptakan menurut kehendak Allah di dalam kebenaran dan kekudusan yang sesungguhnya". Abineno menyebut kedua perbedaan perintah ini sebagai perbedaan negatif dan positif. ${ }^{4}$ Perintah ini disebut perbedaan negatif karena jemaat Efesus diminta untuk berbeda dengan orang yang tidak mengenal Allah, dengan menanggalkan manusia lama sedangkan disebut perbedaan positif, karena jemaat Efesus diperintahkan untuk berbeda dengan orang yang tidak mengenal Allah, dengan mengenakan manusia baru.

Sebagai kata penghubung antara perintah untuk menanggalkan manusia lama dan mengenakan manusia baru, Paulus menggunakan kata "supaya” (kata penghubung untuk menandai tujuan atau harapan). Harapan Paulus terungkap dalam kalimat "supaya kamu dibaharui dalam roh dan pikiranmu". Kata dibaharui dalam teks ini menggunakan

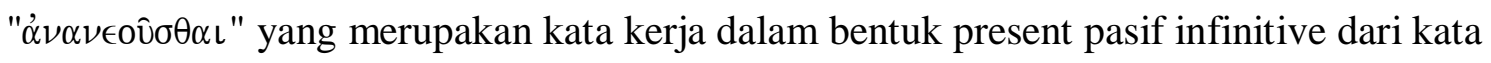

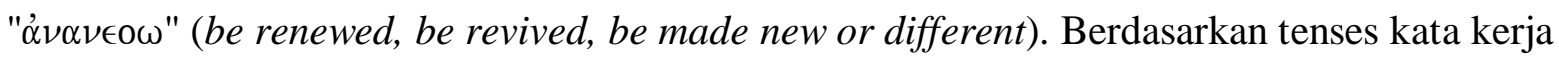
dalam bentuk present menunjukkan bahwa kegiatan ini dilakukan secara terus menerus atau secara berulang-ulang. John Stott menyebutnya sebagai perbuatan atau kelakuan yang berkesinambungan. ${ }^{5}$ Penggunaan bentuk infinitif dalam bahasa Yunani memiliki banyak jenis, namun kata tersebut merupakan bentuk infinitif yang menyatakan akibat dari kata kerja utama (infinitive of result). ${ }^{6}$ Jadi kata ini merupakan akibat dari kata kerja utama, yaitu perintah untuk menanggalkan manusia lama (ayat 22). Selain itu berdasarkan bentuk voicenya kata kerja ini dalam bentuk pasif, di mana subjek dikenai kegiatan kata kerja. Dengan melihat

\footnotetext{
${ }^{4}$ K.L Ch. Abineno, Tafisran Alkitab Surat Efesus, 144.

${ }^{5}$ John R.W Stott, Efesus, 175

${ }^{6}$ Stephano Ambesa, Bahasa Yunani Jakarta: Departemen Pendidikan Gereja Bethel Indonesia, 2006), 49.
} 
perintah Paulus dalam ayat 22 untuk menanggalkan manusia lama, dan dilanjutkan dengan bentuk infinitif "supaya kamu dibaharui", maka dapatlah dipahami bahwa dengan menanggalkan pola hidup manusia lama, mengakibatkan jemaat Efesus secara terus menerus diperbaharui, dibuat kembali, dibuat berbeda dalam roh dan pikirannya. John R.W Stott mengatakan bahwa menjadi Kristen menuntut pembaharuan pikiran secara terus menerus dan kehinaan orang yang tidak mengenal Allah adalah akibat pikirannya yang sia-sia, dan kebenaran Kristen bergantung pada pembaharuan pikiran." 7

Paulus memberikan keterangan "di dalam roh dan pikiranmu”, untuk menjelaskan obyek yang mengalami perubahan secara terus menerus atau berkesinambungan dalam bentuk teks aslinya adalah secara harafiah diterjemahkan the spirit of your mind, ini sesuai dengan terjemahan KJV. LAI menerjemahkannya menjadi dua bagian yang terpisah, yaitu dalam roh dan pikiran, namun berdasarkan teks aslinya dua kata benda ini dihubungkan dengan artikel

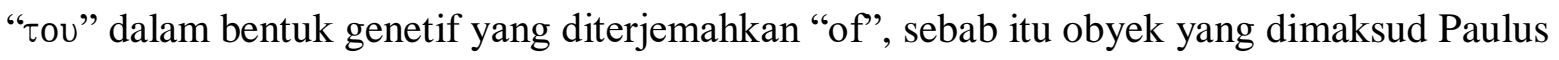
dikenai oleh kegiatan "perubahan secara terus menerus" tersebut hanyalah pada satu obyek

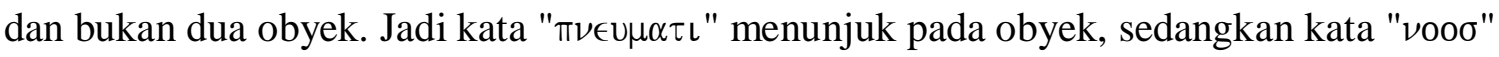
merupakan keterangan obyek.

Secara umum kata $\pi \nu \in \cup \mu \alpha \tau \iota$ memang sering diterjemahkan dengan kata spirit (semangat, roh), namun makna dari kata ini tidak hanya demikian. Oleh Bode kata ini diterjemahkan "roh pikiranmu di dalam kamu", sedangkan menurut terjemahan Roma Katolik terjemahan Indonesia diartikan "di dalam cara berpikir", Schlier mendefinisikannya "oleh roh yang di dalamnya manusia berpikir”. Berdasarkan analisis kata dengan menggunakan software Bible Work 7, kata ini diberi arti; "spirit as part of the human personality", atau "the representative part of the inner life". Firberg Lexicon memberikan arti "as the seat of the inner spiritual life of man", atau dapat juga diartikan sebagai "the capacity to know God".

Beberapa definisi ini menunjukkan bahwa makna "spirit" adalah pusat rohani batin manusia, atau kualitas batin rohani manusia inilah yang menurut Paulus diperbaharui secara terus menerus atau berkesinambungan. Tentu pembaharuan ini adalah karya Allah dalam diri jemaat-jemaat di Efesus yang telah mengenal Kristus.

Setelah menjelaskan pembaharuan pada "kualitas batin rohani manusia", Paulus melanjutkan dengan mengatakan "dan mengenakan manusia baru”. Dalam teks asli kata

\footnotetext{
${ }^{7}$ John Stott, Efesus. 176.
} 
"mengenakan" memakai kata $\epsilon \nu \delta \cup \sigma \alpha \sigma \tau \eta \alpha \iota$ merupakan kata kerja aorist middle infinitive dari kata dasar $\epsilon \nu \delta$ vo (dress, clothe), jadi kata ini dapat diterjemahkan "memakai bagi diri sendiri”. Dengan berpedoman pada penggunaan bentuk infinitif di atas, maka kata kerja pada ayat ini merupakan hasil dari kata kerja sebelumnya, yaitu "dibaharui". Dapatlah dipahami bahwa setiap orang percaya yang "kualitas batin rohaninya" secara terus menerus dibaharui, mengakibatkan dirinya mengenakan manusia baru ( $\alpha \iota \nu \nu \nu \alpha \nu \tau \eta \rho о \pi о \nu)$.

Manusia baru sangat jauh berbeda dengan manusia lama ( $\pi \alpha \lambda \alpha\llcorner\circ \nu \alpha \nu \tau \eta \rho о \pi о \nu)$, manusia lama dikuasai oleh keinginan-keinginan yang jahat, sedangkan manusia baru tidaklah

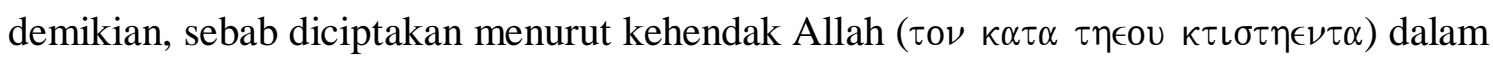
kebenaran dan kekudusan yang sesungguhnya. Kata "kebenaran" menggunakan $\delta \iota \kappa \alpha \iota \sigma \in \mathcal{\nu}$ yang diartikan "sikap prilaku yang sesuai dengan pikiran Allah". Jadi manusia baru yang diciptakan dalam "kebenaran" adalah manusia baru yang sikap hidupnya sesuai dengan nilai moral atau mencirikan sikap hidup dalam Kristus, yaitu sikap yang sesuai dengan keadilan yang berasal dari Allah. Secara sederhana makna kebenaran ini, menjelaskan mengenai suatu perilaku hidup yang baik yang berasal dari Allah. Jadi manusia baru yang diciptakan dalam kebenaran adalah manusia baru yang diciptakan dengan standar moral yang berasal dari Allah.

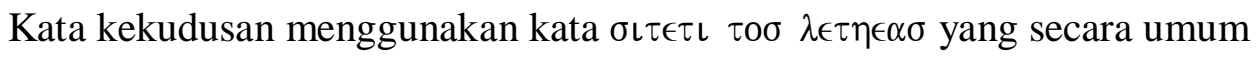
diterjemahkan sebagai holiness atau kesucian. Hal ini berarti manusia baru yang diciptakan dalam "kekudusan" yang sesungguhnya adalah manusia baru yang dari dalam dirinya muncul kesucian oleh karena kebenaran Allah. Kata "yang sesungguhnya" dari kata $\lambda \epsilon \tau \eta \epsilon \alpha \sigma$ yang sering digunakan untuk menunjuk pada ajaran-ajaran Yesus dan kata ini menegaskan kualitas kebenaran dan kekudusan yang membentuk manusia baru. Jadi manusia baru yang diciptakan dalam kekudusan yang sesungguhnya adalah manusia baru yang kesucian hidupnya dilahirkan oleh karena ketundukan pada ajaran-ajaran Kristus atau Firman Allah.

Oleh karena itu manusia baru sangat berbeda dengan manusia lama, sebab manusia baru diciptakan di atas dasar Firman Allah atau kebenaran Ilahi. Sehingga membentuk orang percaya memiliki Kristus dan sikap yang sesuai dengtan keadilan yang berasal dari Allah, dan kesucian hidup yang dilahirkan oleh Firman Allah. Jl. Ch Abineno dalam buku tafsirannya menjelaskan bahwa manusia baru berbeda dengan manusia lama, sebab hidupnya bukan saja 
berpangkal pada Allah, tetapi juga berlangsung di bawah kuasa dan pimpinan-Nya. ${ }^{8}$ Jadi mengenakan pola hidup manusia baru adalah sikap untuk menanggalkan pola hidup manusia lama, yang mana oleh tindakan tersebut manusia dapat mengalami pembaharuan secara terus menerus dalam "kualitas batin rohaninya", dan memiliki kesucian hidup yang dikerjakan oleh Firman melalui pimpinan Roh Kudus.

Manusia baru yang diciptakan dalam "kebenaran yang sesungguhnya memiliki sikap hidup yang sesuai dengan sikap hidup Yesus, yaitu sikap hidup yang sesuai dengan keadilan yang berasal dari Allah. Secara sederhana diciptakan dalam kebenaran yang sesungguhnya adalah suatu perilaku yang baik yang dibangun oleh Firman Allah. Manusia baru yang diciptakan dalam kekudusan yang sesungguhnya adalah manusia baru yang kesucian hidupnya atau kesalehan hidupnya dilahirkan oleh ajaran-ajaran Kristus atau Firman. Jadi dapat disimpulkan bahwa hidup dalam kebenaran dan kekudusan yang sesungguhnya adalah kehidupan moral yang baik dan kesalehan hidup yang baik, yang dibangun oleh kuasa Firman Allah $(\alpha \lambda \eta \theta \in L \alpha \varsigma)$.

Berbicara mengenai manusia lama dan manusia baru adalah berbicara mengenai cara hidup atau pola hidup. Harun Hadiwiyono membedakannya dengan menyebutnya sebagai cara hidup yang lama dan cara hidup yang baru. Sedangkan perubahan dari pola hidup yang lama kepada pola hidup yang baru diistilahkan dengan pembaharuan hidup. ${ }^{9}$ Dalam Efesus 4:23 kita pahami sebagai peristiwa diperbaharui. Pembaharuan itu sendiri mengandung dua perintah, yaitu menanggalkan pola hidup manusia lama dan melakukan pola hidup manusia baru. Pola hidup manusia baru tersebut bukanlah sesuatu yang akan dicipta manusia oleh usahanya yang terbatas, namun pola hidup manusia baru itu telah diciptakan Allah dalam kebenaran dan kekudusan yang sesungguhnya.

Pembaharuan dalam pribadi orang percaya tidak terjadi dalam sekali momen saja, melainkan peristiwa yang terjadi secara terus menerus. Sebab itu pola hidup manusia baru bukanlah suatu hal yang statis, yang berhenti pada level atau kualitas tertentu, melainkan cara hidup yang secara terus menerus (tidak berhenti) diperbaharui untuk memperoleh pengetahuan yang benar tentang Allah. Menurut Harun Hadiwiyono, pembaharuan yang

\footnotetext{
${ }^{8} \mathrm{Jl}$. Ch Abineno, Tafisran Alkitab Surat Efesus, 145.

${ }^{9}$ Harun Hadiwiyono, Iman Kristen, 196.
} 
menuju kepada pengetahuan yang benar tentang Allah, sepadanan dengan kesamaan ilahi atau menjadikan sesuai dengan gambaran Allah. ${ }^{10}$

Menurut Harun Hadiwiyono, alasan Allah membentuk manusia dalam kebenaran dan kekudusan adalah karena Allah sendiri adalah benar dan kudus. ltu sebabnya manusia yang diperbaharui menjadi manusia baru seharusnya menampakkan hidup yang benar dan kudus pula. ${ }^{11}$ Allah yang adalah benar tampak dalam sebutannya sebagai Bapa yang adil (Yoh. 17:25). Allah yang adil secara mutlak, menghakimi dengan keadilan yang mutlak pula. ${ }^{12}$ Tindakan keadilan mutlak yang Allah lakukan menunjukkan bahwa Dia Allah yang adalah benar.

\section{Eksposisi Efesus 4:25}

Menindak lanjuti penjelasan mengenai konsep dasar manusia baru. Paulus menjelaskan konsep tersebut dalam nasehat dan perintah konkret. Paulus mengatakan "buanglah dusta dan berkatalah benar". Kata "buanglah" dalam teks asli menggunakan kata $\alpha \pi \circ \theta \in \mu \in \nu$ o dalam bentuk aorist middle participle (imperatif) orang kedua jamak dari kata $\alpha \pi$ $\tau \iota \theta \eta \mu \iota$ (throw off, take off). Kata kerja dalam bentuk aorist middle participle menunjukan suatu kegiatan yang sudah selesai mendahului kata kerja sebelumnya, ${ }^{13}$ di mana subyek melakukan kegiatan tersebut untuk dirinya sendiri. Jadi kegiatan "menanggalkan dusta" ( $\psi \in \cup \delta \delta \varsigma)$, merupakan tidakan awal sebelum mengenakan manusia baru.

Selanjutnya adalah frase "berkatalah benar" ( $\lambda \alpha \lambda \epsilon \iota \tau \epsilon \alpha \lambda \eta \theta \epsilon \iota \alpha \nu)$. Kata "berkatalah" menggunakan teks asli $\lambda \alpha \lambda \alpha \epsilon \iota \epsilon$ adalah kata kerja dalam bentuk present active imperative orang kedua jamak dari $\lambda \alpha \lambda \epsilon_{\mathrm{o}}$ (speak as with a message, talk). Kata kerja dalam bentuk present active imperative adalah suatu perintah untuk melanjutkan sebuah kegiatan yang sedang berlangsung, yang dilakukan secara terus menerus."14 Jadi Paulus ingin menjelaskan kepada jemaat Efesus untuk menanggalkan atau melepaskan kebohongan, dan secara terus menerus berbicara atau menyampaikan pesan yang benar $(\alpha \lambda \eta \theta \in \iota \alpha \nu)$. Dalam hal ini $\alpha \lambda \eta \theta \epsilon \iota \alpha \nu$

\footnotetext{
${ }^{10}$ Harun Hadiwiyono, 197.

${ }^{11}$ Ibid., 198.

${ }^{12}$ Donal Guthrie, Teologi Perjanjian Baru 1, 79.

${ }^{13}$ Stephano Ambesa, Bahasa Yunani, 28.

${ }^{14}$ Stephano Ambesa., 38
} 
mengandung makna "what has certainty and validity of truth" (apa yang mempunyai kepastian dan kevalid-an kebenaran).

Implementasi manusia baru dalam hal berbicara sesuai kebenaran adalah melepaskan kebohongan atau dusta, dan secara terus menerus menyampaikan pesan yang benar (hal yang mempunyai kepastian dan kevalid-an kebenaran). Kebohongan atau berdusta merupakan sifat dari manusia lama, sebab manusia lama itu tidak jujur. Manusia lama penuh dengan kepalsuan dan kemunafikan, dan di hadapan sesamanya ia menggunakan topeng. Namun manusia baru tidaklah demikian, ia diciptakan dalam kebenaran dan kekudusan yang sesungguhnya, yang menggantikan dusta dengan berkata benar.

Dalam berkomunikasi hal yang sangat diperlukan adalah kredibilitas, dan kredibilitas tersebut dibangun di atas dasar kejujuran (berkata benar). Ungkapan lama yang berkata "katakanlah apa yang anda maksudkan dan bersungguh-sungguhlah dengan apa yang anda katakan" mencerminkan prinsip yang Alkitabiah. ${ }^{15}$ Salah satu dari unsur-unsur utama dalam hubungan manusia yang baik adalah hal kebenaran. Dalam Kolose 3:9 dijelaskan "jangan lagi kamu saling mendustai, karena kamu telah meninggalkan manusia lama serta kelakuannya" dan dalam Efesus 4:25 dikatakan "karena itu berkatalah benar". Dusta merusak kepercayaan seseorang pada orang yang mendustainya. Sesudah kepercayaan itu hilang, maka hubungan akan sulit untuk dipulihkan kembali. Namun terkadang kebiasaan berdusta itu dapat berkembang dengan cara yang begitu halus, sehingga kebiasaan tersebut berlangsung tanpa diperhatikan. Dimulai dari berdusta tentang hal-hal yang sederhana, yang dianggap tidak akan menciptakan masalah, namun kemudian hal itu berkembang menjadi suatu pola hidup maka kredibilitas dan persahabatan-persahabatan yang berharga hilang. Jerry White dalam bukunya menjelaskan beberapa bentuk tindakan kebohongan atau dusta, yang mencirikan pola hidup manusia lama, di antaranya adalah fitnah, tipu daya, dan bersikap diam saja.

a. Fitnah

Fitnah didefinisikan sebagai ucapan dakwaan-dakwaan palsu atau penggambaranpenggambaran salah, yang mencemarkan dan merusak nama baik orang lain. Lebih khusus, fitnah juga dapat diartikan sebagai penyampaian dusta tentang orang lain. ${ }^{16}$ Alkitab berbicara tentang fitnah dalam Mazmur 101:5 “orang yang sembunyi-sembunyi mengumpat temannya,

\footnotetext{
${ }^{15}$ Jerry White, Kejujuran Moral Dan Hati Nurani (Jakarta: BPK Gunung Mulia, 2004), 128.

${ }^{16}$ Jerry White, Kejujuran Moran Dan Hati Nurani, 39.
} 
dia akan kubinasakan". Pada bagian lain dikatakan bahwa orang-orang yang tetap bersamasama dengan Allah tidak menyebarkan fitnah dengan lidahnya (Maz. 15:3). Paulus melukiskan bahwa pada akhir zaman manusia akan lebih suka menjelekkan orang lain (2 Tim. 3:3) Sebab itu kita perlu rnenanggalkan dusta atau perkataan busuk dari lidah kita dan pikiran kita, sebab fitnah dapat terjadi bahkan dengan tidak disengaja.

\section{b. Tipu Daya}

Memperdayakan berarti membuat seseorang menerima sebagai benar apa yang palsu dan salah. Hal ini berarti tindakan secara sengaja menipu, sebab telah berusaha memberi kesan yang salah atau membohongi. Daud mencerminkan pandangan Allah tentang hal itu tipu daya ketika dia berkata; "orang-orang melakukan tipu daya tidak akan diam di dalam rumahku, orang berbicara dusta tidak akan tegak di depan mataku” (Maz 101:7). Pada bagian lain Firman Allah melalui tulisan Daud juga menegaskan bahwa perkataan orang yang jahat "adalah kejahatan dan tipu daya, sebab ia berhenti berlaku bijaksana dan berbuat yang baik" (Maz. 36:4).

Dalam Kolose 2:8 diajarkan "hati-hatilah, supaya jangan ada yang menawan kamu dengan filsafatnya yang kosong dan palsu menurut ajaran turun-temurun dan roh-roh dunia, tetapi tidak menurut Kristus”. Namun sebaliknya, orang percaya diperintahkan untuk membuang segala kejahatan, segala tipu muslihat, dan segala macam kemunafikan (1Pet. 2.1). Petrus juga berkata "Siapa yang mau mencintai hidup dan mau melihat hari-hari baik, ia harus menjaga lidahnya terhadap yang jahat dan bibirnya terhadap ucapan yang menipu (1Pet. 3:10). Adalah mempraktekkan tipu daya bila seseorang mempengaruhi orang lain untuk mempercayai suatu yang tidak dapat dibuktikan kebenarannya.

\section{c. Diam Saja}

Bersikap diam saja bersama orang yang sedang mengatakan dusta adalah tidak jujur. Allah tidak membenarkan tindakan demikian, bersikap diam terhadap pembohongan hanya agar tidak dirugikan. Jadi bilamana seseorang tidak mengatakan suatu kebohongan atau ketidakjujuran, sehingga oleh tindakannya tersebut orang lain tertipu, maka tindakan ini sama halnya dengan tindakan berbohong terhadap orang yang tertipu tersebut. Itu sebabnya dalam Yakobus 4:17 dikatakan "jadi jika seorang tahu bagaimana ia harus berbuat baik, tetapi ia tidak melakukannya, ia berdosa". Ada banyak kesempatan atau peristiwa yang sebenarnya 
seorang percaya yang harus mengatakan kebenaran dan memperingatkan kesalahan, tetapi tindakan bungkam karena takut atau karena ingin menghindari ancaman terhadap diri sendiri, maka hal tersebut adalah tindakan pendiaman kebohongan dan kejahatan. Jerry White mengatakan bahwa orang percaya harus berani memperkatakan kebenaran tanpa peduli akibatnya. ${ }^{17}$

\section{Eksposisi Efesus 4:26-27}

Selanjutnya Paulus menasehati jemaat Efesus dengan berkata “apabila kamu menjadi marah, janganlah kamu berbuat dosa; janganlah matahari terbenam, sebelum padam amarahmu, dan janganlah beri kesempatan kepada Iblis". Kata "menjadi marah"

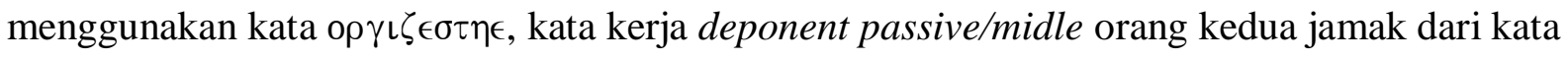

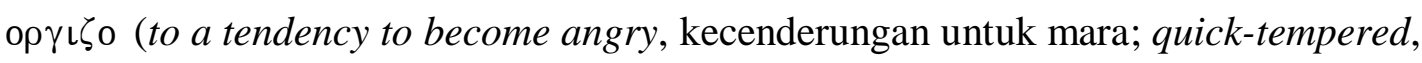
tempramental). Deponent adalah kata kerja bentuk passive/middle tetapi memiliki fungsi aktif. ${ }^{18}$ Jadi Paulus menasehatkan bilamana mereka bersikap cepat marah; memiliki kecenderungan marah; atau bersikap temperamental, jangan berbuat dosa.

Kata "berbuat dosa" dalam teks asli $\alpha \mu \alpha \rho \tau \alpha \nu \in \tau \in$ yang merupakan kata kerja present aktif imperative dari kata dasar $\alpha \mu \alpha \rho \tau \alpha \nu \omega$ (do wrong, berbuat kesalahan; miss the mark, tidak tepat sasaran). Berdasarkan fungsi kata kerja present active imperative, yaitu sebagai perintah untuk melanjutkan sebuah kegiatan yang sedang berlangsung, maka kata ini dapat diartikan; “janganlah kamu secara terus menerus berbuat kesalahan, atau tidak tepat sasaran (tidak sesuai dengan yang Allah kehendaki)". Jadi Paulus berkata bahwa amarah manusia adalah kesalahan, sebab itu ia menegaskan supaya tidak secara terus menerus melakukan kesalahan (amarah).

Implementasi manusia baru dalam hal menguasai diri dari kecenderungan amarah adalah tidak secara terus menerus bersikap marah, sebab amarah manusiawi adalah kealahan (dosa) dihadapan Allah. Doktor Ligon, seorang teolog dan psikolog dalam salah satu bukunya Psychology Of The Christian Personality menuliskan "bila seorang psikolog diminta untuk menyebutkan dua dosa utama dari sudut pandang mereka, maka kemungkinan besar mereka

\footnotetext{
${ }^{17}$ Jerry White, Kejujuran Moral dan Hati Nurani. 42.

${ }^{18}$ Stephano Ambesa, Bahasa Yunani, 14.
} 
akan menyebutkan amarah dan ketakutan sebagai biang dosa. ${ }^{19}$ Dua hal ini menjadi akar dari sebagian besar ketidakbahagiaan manusia, yang menyebabkan sulitnya seseorang memiliki kepribadian yang sehat. Akar amarah yang paling dalam adalah harga diri dan kepentingan pribadi. Bila salah satu dari keduanya disentuh, maka serta merta darahnya akan mendidih. Amarah ini bisa terluapkan bila mendapatkan kesempatannya, namun kadangkala tertahan karena tidak merasa memiliki kekuatan. Oleh sebab itu amarah tidak akan mungkin untuk dilenyapkan, namun harus dikendalikan, yaitu dengan mengendalikan akar-akarnya. ${ }^{20}$

Pada satu pihak, kisah penderitaan Yesus adalah kisah yang paling dramatis, dimana harga diri dan kepentingan pribadinya tidak dihargai. Namun dari kisah tersebut, Yesus berhasil mendemonstrasikan, bagaimana Ia mampu mengendalikan dua akar penyebab amarah tersebut. Yesus tidak pernah berusaha untuk membela diri, kecenderungan kepentingan pribadi dan harga diri Yesus letakkan di bawah ketaatan dan penyerahan diri-Nya yang total kepada Allah. Demi ketaatannya kepada Allah, Yesus bersedia untuk menanggung apa pun, tanpa amarah. Jadi jelas bahwa orang percaya hanya dapat menguasai diri dari amarah bilamana menguasai akar amarah tersebut dalam ketaatan pada perintah untuk mengenakan manusia baru.

Memang harus diakui bahwa tidak semua jenis marah dapat dikatakan dosa, namun semua amarah akan menjadi dosa ketika amarah itu tidak didasarkan pada orientasi kebenaran Allah. Yesus pernah marah ketika melihat kedegilan hati orang-orang di sekelilingnya (Mrk. 3:15). Namun amarah Yesus berpadu dengan dukacita, dengan kesedihan yang mendalam, dengan kepahitan yang menyakitkan karena orang banyak tidak mengerti kebenaran Allah. Inilah amarah yang benar, yang didasarkan dan ditujukan kepada kebenaran Allah. Namun, amarah manusia yang berorientasi pada panas hati, iri hati, atau kebencian pribadi adalah kesalahan atau dosa di hadapan Allah dan harus ditanggalkan.

\section{Eksposisi Efesus 4:28}

Selanjutnya Paulus menasehati jemaat Efesus dengan berkata "orang yang mencuri, janganlah ia mencuri lagi, tetapi baiklah ia bekerja keras dan melakukan pekerjaan yang baik dengan tangannya sendiri, supaya ia dapat membagikan sesuatu kepada orang yang

${ }^{19}$ Eka Darmaputera, Anak Tangga Menuju Hidup Berkemenangan (Jakarta: BPK Gunung Mulia, 2008), 318.

${ }^{20}$ Eka Darmaputera, Anak Tangga Menuju Hidup Berkemenangan, 320. 
berkekurangan". Menurut Abineno, nasehat Paulus tentang hal mencuri menunjukkan bahwa masih terdapat pencurian dalam jemaat Efesus. Abineno menentang tafsiran yang menjelaskan bahwa nasehat mencuri ini ditujukan hanya pada kelompok hamba-hamba Kristus yang melayani jemaat. ${ }^{21}$ Sebab tidak ada acuan yang mengarahkan pada penunjukan kelompok hamba-hamba Kristus, sebagai kelompok yang sedang dinasehati Paulus. Mencuri ( $\kappa \lambda \epsilon \pi \tau \epsilon \tau)$ adalah take away something secretly, without the owner's permission (mengambil secara diam-diam sesuatu, tanpa seizin pemiliknya). Jadi Paulus menasihati jemaat Efesus untuk menanggalkan sikap yang secara diam-diam mengambil milik orang lain tanpa seizin pemiliknya.

Rendtorf dalam menjelaskan perbedaan antara manusia lama dan manusia baru mengatakan:

bahwa manusia yang jauh dari Allah adalah manusia lama, yang hanya mengenal keinginan untuk memiliki, untuk menarik segala sesuatu kepada dirinya sendiri, sekalipun untuk hal itu ia harus melakukan kejahatan secara terang-terangan. Dan sebaliknya manusia yang dipenuhi oleh kasih Kristus adalah manusia baru, yang mengenal sikap hidup yang melayani, mengenal tugas dan pekerjaan di mana ia berada sebagai anggota. ${ }^{22}$

Setelah Paulus menasehati tentang hal mencuri, ia melanjutkan dengan perintah "bekerja

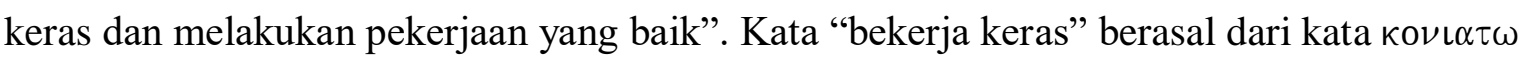

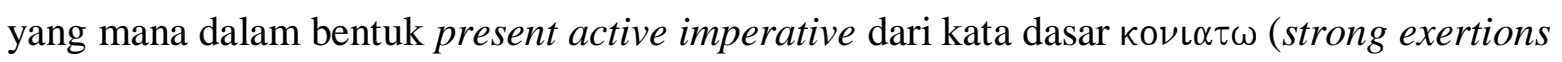
work hard, pengerahan tenaga yang kuat untuk bekerja keras; struggle, berusaha). Perintah bekerja keras ini juga disertai nasehat untuk bekerja "pada pekerjaan yang baik" ( Bode dalam tafsirannya menjelaskan pekerjaan yang baik adalah pekerjaan yang dilakukan dengan dasar kejujuran. ${ }^{23}$

Berdasarkan pengertian-pengertian tersebut, mengenakan pola hidup manusia baru adalah bekerja keras dengan jujur dan dengan cara yang terhormat, serta bekerja tidak hanya untuk diri sendiri tetapi untuk orang lain yang berkekurangan. Pola hidup seperti inilah yang membedakan antara manusia lama dan manusia baru. Menurut Van Leeuwen, motif kasih seperti ini besar sekali artinya dalam masa gereja mula-mula. Demikianlah pada waktu orang percaya mengalami siksaan, orang-orang Kristen bekerja membanting tulang supaya mereka

\footnotetext{
${ }^{21}$ Jl. Ch Abineno, Tafsiran Alkitab Surat Efesus, 149.

${ }^{22}$ Ibid., 149.

${ }^{23} \mathrm{Jl}$. Ch Abineno., 150
} 
dapat mengirimkan uang dan barang-barang lain kepada saudara-saudara seiman yang dipaksa bekerja di tambang-tambang.

Implementasi manusia baru dalam hal bekerja secara maksimal untuk menjadi berkat adalah pemaksimalan tenaga untuk bekerja secara jujur dan dengan cara yang terhormat, dengan tujuan dapat memberikan pertolongan kepada orang lain yang berkekurangan. Pada bagian awal perintah untuk bekerja secara maksimal, Paulus menegur mereka untuk menanggalkan sikap mengambil sesuatu tanpa seizin pemiliknya (mencuri). Namun sebaliknya diperintahkan untuk bekerja keras, sehingga dapat memberikan bantuan kepada orang yang berkekurangan.

Setiap manusia yang hidup membutuhkan kerja keras dan perjuangan. Untuk mencapai keberhasilan dan kesuksesan pun sangat diperlukan kerja keras dan perjuangan dalam dunia ini tidak ada kehidupan manusia yang mengesampingkan kerja keras, dari level atas sampai level bawah. Kata "kerja keras" menjadi poin yang dominan. Untuk menjadi seorang yang profesional dalam bidang apapun, kerja keras pasti menjadi dasarnya. Abineno mengatakan dalam bukunya, bahwa menjadi manusia baru tidak berarti duduk bermalasmalasan kemudian berharap diberkati, ${ }^{24}$ tetapi pola hidup manusia baru mengatakan bahwa orang percaya harus bekerja keras. Sebab Allah yang adalah benar dan kebenaran itu sendiri, secara mutlak melakukan hukum keadilannya. Allah yang benar memandang ketidakmaksimalan atau tindakan tidak bekerja keras sebagai kesalahan di hadapan-Nya.

Paulus juga menegaskan bahwa tujuan dari bekerja secara maksimal bukan sematamata hanya untuk memenuhi kebutuhan sendiri pola hidup manusia baru menghendaki setiap orang percaya menjadi berkat bagi orang yang berkekurangan. Tindakan untuk menjadi berkat bagi orang yang berkekurangan disebut pelayanan diakonia. Dalam peristiwa-peristiwa di Perjanjian Baru kata $\delta\llcorner\alpha \nu \kappa \nu \in \iota \nu$ (harfiah: "melayani di meja"), contohnya tujuh orang yang penuh hikmat, dan penuh Roh dipilih untuk melayani meja (Kis. 6:2), mengenai para wanita yang mengikut Yesus dikatakan mereka melayani-Nya ( $\delta\llcorner\alpha \kappa o \nu \in \iota \nu)$ dengan harta benda (Luk. 8:3). Dalam Mat. 25:31-46, dilukiskan pelayanan ( $\llcorner\alpha \kappa о \nu \epsilon \iota \nu)$ sebagai memberi makan dan minum, memberi pakaian dan tumpangan, perawatan dan kunjungan orang sakit serta para

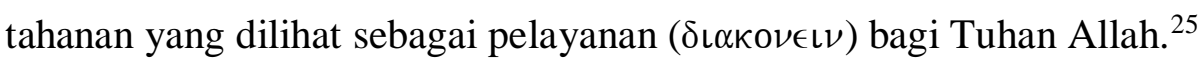

\footnotetext{
${ }^{24}$ Ibid., 150.
}

${ }^{25}$ A. Noodegraaf, Orientasi Diakonia Gereja (Jakarta: BPK Gunung Mulia, 2004). 7 
Jadi dapatlah kita simpulkan bahwa pelayanan diakonia mencakup pelayanan yang sangat luas, yaitu semua pekerjaan yang dilakukan dalam pelayanan bagi Kristus, memberi bantuan kepada semua orang yang mengalami kesulitan dalam kehidupan masyarakat. Pola hidup manusia baru bercirikan pribadi yang bekerja secara maksimal dan tidak hidup untuk kepentingannya sendiri, melainkan berusaha untuk menjadi berkat bagi orang lain yang membutuhkan.

\section{Eksposisi Efesus 4:29-30}

Selanjutnya Paulus mengatakan: "Janganlah ada perkataan kotor keluar dari mulutmu, tetapi pakailah perkataan yang baik untuk membangun, di mana perlu, supaya mereka yang mendengarnya, beroleh kasih karunia. Dan janganlah kamu mendukakan Ron Kudus Allah, yang telah memeteraikan kamu menjelang hari penyelamatan". "Perkataan kotor" menggunakan kata $\lambda$ ○оo $\sigma \alpha \pi \rho \circ \sigma$, kata $\sigma \alpha \pi \rho \circ \sigma$ pada umumnya digunakan untuk menjelaskan keadaan ikan yang telah menjadi busuk, atau buah-buahan yang tidak lagi berguna untuk dimakan karena kotor. Secara umum kata ini menjelaskan sesuatu yang tidak berguna. John R W Stott mendefinisikan kata ini sebagai perkataan yang kasar yang berpotensi menyinggung pendengarnya. ${ }^{26}$

Jadi Paulus melarang jemaat memperkatakan perkataan busuk, kotor atau tidak berguna. Sebab perkataan demikian adalah pola dari kehidupan manusia lama yang harus ditanggalkan. Menurut Abineno, penggunaan kata " $\pi \alpha \sigma$ " di awal kalimat di awal kalimat dan penggunaan $\mu \omega$ pada $\epsilon \kappa \pi$ $\epsilon \epsilon \cup \sigma \tau \eta \omega$ di akhir kalimat, menunjukkan bahwa dalam hati manusia terdapat kata-kata yang kotor (busuk, dan jahat), yang berusaha ingin melonjak keluar. ${ }^{27}$ Mengingat potensi yang demikian dalam hati manusia inilah Paulus menegaskan jemaat Efesus, supaya tidak memakai perkataan kotor, melainkan perkataan yang baik ( $\alpha \gamma \alpha \tau \eta о \sigma)$.

Paulus secara konkret menjelaskan bahwa perkataan yang baik yang dimaksudkannya

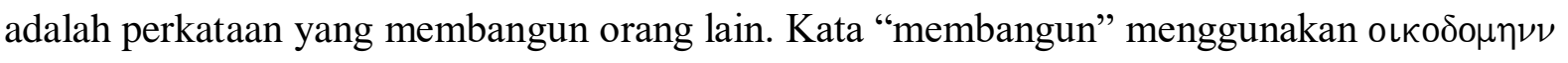
secara literal diartikan "building, construction", secara figurative dapat diartikan "spiritual encouragement making more able" (dorongan rohani yang membuat lebih mampu/sanggup). Jadi pola hidup manusia baru adalah memperkatakan perkataan membangun orang lain, atau

\footnotetext{
${ }^{26}$ John R.W Stott, Efesus, 182.

${ }^{27}$ J1. Ch Abineno, Tafsiran Alkitab Surat Efesus, 150.
} 
memberi dorongan rohani yang membuat seseorang menjadi lebih kuat, lebih mampu, lebih bersemangat.

Untuk menegaskan kembali perintah yang telah dijelaskan sebelumnya, dengan menanggalkan perkataan kotor, dan memperkatakan perkataan yang membangun orang lain (memberi dorongan rohani yang membuat seseorang menjadi lebih kuat, dan lebih bersemangat), maka hal ini tidak mendukakan Roh Kudus. Tetapi bila hidup dengan pola hidup manusia lama, Roh Kudus didukakan oleh pola hidup tersebut. lmplementasi manusia baru dalam hal memperkatakan yang baik untuk membangun adalah membuang perkataan kotor, tidak santun, perkataan yang berpotensi menyinggung perasaan orang lain dan secara aktif menggantikannya dengan perkataan yang baik, perkataan yang memberi dorongan rohani sehingga membuat seseorang menjadi lebih kuat dan mampu, dan lebih bersemangat.

Yesus mengajar perihal perkataan, sebab kata-kata merupakan isi hati, dan setiap katakata yang sia-sia diucapkan harus dipertanggungjawabkan pada hari penghakiman (Mat. 12:36). Yakobus mengulangi kembali ajaran Yesus ini ketika ia menekankan betapa besarnya kuasa lidah untuk membuat yang baik atau yang jahat (Yak. 3:1-12). Sebab itu peranan perkataan seseorang menentukan pola hidupnya, perkataan kotor menyebabkan kekacauan, namun perkataan yang baik membangun rohani dan semangat orang lain yang mendengarkannya.

Semua persahabatan yang mendalam tidak dapat berkembang bila percakapan yang dimiliki ditandai dengan kata-kata yang menyinggung perasaan dan menyakiti hati orang lain, sekalipun hal itu diutarakan dengan lelucon, kata-kata lucu yang bersifat buruk dan kasar. ${ }^{28}$ Sebab itu manusia baru harus berbicara dengan sopan dan dengan cara yang menyenangkan kepada orang-orang lain. Sebab perkataan yang baik dapat membangun semangat dan member dorongan rohani pada orang yang mendengarkannya. Namun hal ini tidak didasarkan pada tujuan agar dapat diterima dalam kelompok tertentu.

\section{Eksposisi Efesus 4:31-32}

Selanjutnya Paulus mengatakan, "Segala kepahitan, kegeraman, kemarahan, pertikaian dan fitnah hendaklah dibuang dari antara kamu, demikian pula segala kejahatan. Tetapi hendaklah kamu ramah seorang terhadap yang lain, penuh kasih mesra dan saling

${ }^{28}$ Jerry White, Kejujuran Moral dan Hati Nurani, 52. 
mengampuni, sebagaimana Allah di dalam Kristus telah mengampuni kamu”. Kata "kepahitan" menggunakan $\pi \iota \kappa \rho\llcorner\alpha$ didefinisikan "hostile attitude, sikap bermusuhan;

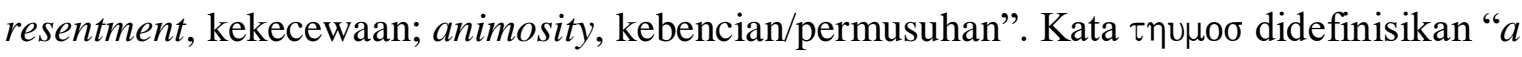
strong passion of mind wrath, gairah yang kuat dari amarah pikiran; angry heat, amarah yang

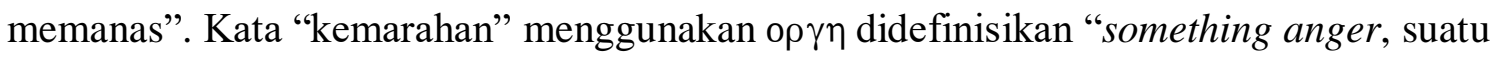
amarah; wrath, marah besar; indignation, perasaan berang". Kata "pertikaian" menggunakan

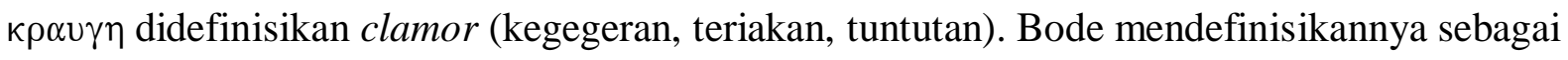
tindakan gaduh, sedangkan terjemahan Roma-Katholik adalah teriakan karena marah dan karena itu timbul kegaduhan dan sebagainya. ${ }^{29}$ Kata berikutnya adalah "fitnah" menggunakan $\beta \lambda \alpha 0 \pi \eta \in \mu \iota \alpha$ didefinisikan "abusive speech against someone reputation" (pidato kasar terhadap reputasi seseorang).

Setelah menjelaskan nasehat untuk menanggalkan kepahitan, kegeraman, kemarahan, pertikaian, fitnah, dan segala kejahatan, Paulus menyatakan suatu pertentangan atau nasihat sebaliknya dari ayat 31 di mana perintah ini dimulainya dengan kata $\gamma \iota \nu \in \sigma \theta \epsilon \delta \in$ (tetapi hendaknya) ramah, penuh kasih mesra, dan pengampunan seorang terhadap yang lain. Kata

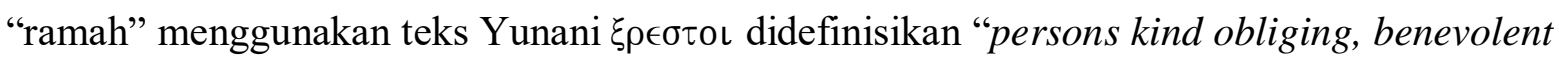
(jenis pribadi penurut, murah hati)". Menurut John R.W Stott, penggunaan kata ini pada masa awal gereja digunakan untuk menyebut orang-orang Kristen. ${ }^{30}$ Jadi karakter murah hati menjadi ciri khas seorang Kristen pada masa itu. Sedangkan kata "kasih mesra" menggunakan $\epsilon \cup \sigma \pi \lambda \alpha \gamma \chi \eta \nu \mathrm{O}$ didefinisikan "compassionate" (simpatik, pantas dikasihani). Bode mendefinisikannya sebagai lembut hati sedangkan terjemahan Roma-Katholik adalah murah hati. Untuk menegaskan perintah agar bersikap ramah (pribadi penurut, murah hati), dan penuh "kasih mesra" (lembut hati, murah hati), Paulus mengatakan agar hal itu dinyatakan dengan saling mengampuni ( $\alpha_{\alpha \iota} \zeta \mathrm{o} \mu \epsilon_{\nu} \mathrm{ol}$ - present middle imperative). Implementasi manusia baru dalam hal penuh kasih mesra adalah menanggalkan kepahitan hati (kebencian, sikap permusuhan), kegeraman (gairah kemarahan), pertikaian (kegegeran, kegaduhan), fitnah, dan menjadi pribadi yang ramah (penurut, murah hati), penuh kasih mesra (simpatik, lembut hati), dan di dalam segalanya dapat mengampuni.

\footnotetext{
${ }^{29}$ Jl. Ch Abineno, Tafisran Alkitab Surat Efesus, 154.

${ }^{30}$ John R.W Stoot, Efesus, 184.
} 
Henri menyatakan, kita menjadi semakin sadar bahwa kita mencintai hanya karena kita sudah dicintai terlebih dahulu dan bahwa kita dapat menawarkan kasih mesra hanya karena kita sudah dilahirkan dari kasih mesra Allah sendiri. ${ }^{31}$ Sebab itu orang yang telah mengalami kasih Kristus, memiliki hati yang penuh kasih mesra. John Drescher berkata bahwa kasih mesra itu berarti sadar akan perasaan orang lain dan mampu mengadaptasikan perkataan dan tingkah laku yang sesuai. ${ }^{32}$ Catherine Marshall dalam bukunya Something More mengatakan bahwa mengampuni berarti melepaskan orang lain dari penghakiman pribadi kita bukan berarti kita menyetujui perkataan atau perbuatannya yang salah, melainkan melalui tindakan tersebut kita menyatakan bahwa anda tidak bertindak sebagai hakimnya. ${ }^{33}$

Hati yang penuh pengampunan tidak bertindak menghakimi kelemahan dan dosa yang lain yang kelihatan. Secara prinsip, pengampunan adalah tugas manusia dan penghakiman adalah tugas Allah. Jadi manusia baru adalah pribadi yang hatinya penuh dengan kasih mesra dan pengampunan yang olehnya orang lain diberkati. Jerry Cook mengatakan "bila kasih mesra dan pengampunan menjadi ciri-ciri hidup orang percaya, maka Tuhan akan mengirim kepada orang percaya tersebut orang-orang yang perlu dijadikan lengkap dan utuh. ${ }^{34}$ Bila kasih mesra dan pengampunan menjadi ciri kehidupan Kristen, maka orang percaya akan memainkan peran seperti halnya Kristus selama pelayanan-Nya di dunia. Orang percaya menjadi pusat kasih dan penyembuhan bagi orang-orang yang hampir hancur.

\section{KESIMPULAN}

Berdasarkan eksegese Efesus 4:23-32 tentang spiritualitas manusia baru, maka ditemukan beberapa perilaku hidup manusia baru, orang percaya yang hidup dalam kebenaran dan kekudusan yang sesungguhnya. Orang percaya berbicara sesuai dengan kebenaran, maksudnya tidak berkata fitnah atau memperkatakan dakwaan-dakwaan palsu atau penggambaran-penggambaran salah, yang mencemarkan dan merusak nama baik orang lain. Dalam hal berbicara, orang percaya tidak boleh bersikap diam saja bersama orang sedang

\footnotetext{
${ }^{31}$ Henri J.M Noumen, Mengapa Kematangan Hidup Rohani (Yogyakarta: Kanisius, 1985). 126.

${ }^{32}$ John Drescher, Melakukan Buah Roh, 159.

${ }^{33}$ Jerry Cook, Kisah Penerimaan Dan Pengampunan (Jakarta: BPK Gunung Mulia, 1990). 17.

${ }^{34}$ Jerry Cook, Kisah Penerimaan Dan Pengampunan, 18.
} 
mengatakan dusta adalah tidak jujur. Allah tidak membenarkan tindakan bersikap diam terhadap pembohongan hanya agar tidak dirugikan.

Selanjutnya adalah berperilaku menguasai diri dari kecenderungan amarah. Amarah manusia yang berorientasi pada panas hati, iri hati, kebencian pribadi adalah kesalahan atau dosa di hadapan Allah dan harus ditanggalkan. Orang percaya bekerja maksimal untuk menjadi berkat bagi orang lain. Pola hidup manusia baru bercirikan pribadi yang bekerja secara maksimal dan tidak hidup untuk kepentingannya sendiri, melainkan berusaha untuk menjadi berkat bagi orang lain yang membutuhkannya. Orang percaya memperkatakan yang baik untuk membangun. Semua persahabatan yang mendalam tidak dapat berkembang bila percakapan yang dimiliki ditandai dengan kata-kata yang menyinggung perasaan dan menyakiti hati orang lain, sekalipun hal itu diutarakan dengan lelucon, kata-kata lucu yang bersifat buruk dan kasar. Perilaku terakhir yang menggambarkan spiritualitas manusia baru adalah berperilaku penuh kasih mesra. Bila kasih mesra dan pengampunan menjadi ciri kehidupan Kristen, maka orang percaya akan memainkan peran seperti halnya Kristus selama pelayanan-Nya di dunia. 


\section{DAFTAR PUSTAKA}

A. Noodegraaf, Orientasi Diakonia Gereja. Jakarta: BPK Gunung Mulia, 2004.

Adina Chapman, pengantar Perjanjian Baru. Bandung Yayasan Kalam Hidup, 2004.

Alfian B. Satria, Skripsi Tesis \& Disertasi. Yogyakarta: Immortal Publisher, 2010.

Andi Prastowo, Metode Penelitian Kualitatif. Yoyakarta: AR-RUZZ MEDIA, 2012.

Clinton E. Arnold, Ephesians Letter to the. Dictionary of Paul and Hid Letter).

Conny R. Semiawan, Metode Penelitian Kualitatif: Jenis, Karakteristik dan Keunggulannya. Jakarta: PT. Grasindo, t.t.

Dolet Unaradjan, Pengantar Metode Penelitian Ilmu Sosial. Jakarta: PT. Grasindo, 2000.

Donald Guthrie, Tafsiran Alkitab Masa Kini. Jakarta: Komunikasi Bina Kasih, 2001.

Eka Darmaputera, Anak Tangga Menuju Hidup Berkemenangan. Jakarta: BPK Gunung Mulia, 2008.

GIDION, Gidion. Memahami Pekerjaan Roh Kudus dalam Pelayanan Gereja Berdasarkan 1 dan 2 Timotius. HARVESTER: Jurnal Teologi dan Kepemimpinan Kristen, 2019, 4.2: 108-121.Hariwijaya, Pedoman Penulisan Skripsi dan Tesis. Yogyakarta: ORYZA, 2011.

Henri J.M Noumen, Mengapa Kematangan Hidup Rohani. Yogyakarta: Kanisius, 1985.

J.I. Ch. Abineno, Tafsiran Alkitab Surat Efesus. Jakarta: BPK Gunung Mulia, 1989.

J.I. Packer, Meriil C. Tenny, Wiliam White Jr, Ensiklopedi Fakta Alkitab Bible Almanac 2. Malang: Gandum Mas, 2004.

Jerry Cook, Kisah Penerimaan Dan Pengampunan. Jakarta: BPK Gunung Mulia, 1990. Jerry White, Kejujuran Moral Dan Hati Nurani. Jakarta: BPK Gunung Mulia, 2004.

John Calvin, Calvins Bible Comentary: Galatia and Ephesians. Forgotten Books, 1847.

John R. W. Stoot, Efesus. Jakarta: Yayasan Komunikasi Bina Kasih/ OMF, 2000.

Jonathan Sarwono, Metodologi Penelitian Kuantitatif dan Kualitatif. Yogyakarta: Graha Ilmu, 2006.

M. Djunaidi Ghony \& Fauzan Almansur, Metode penelitian Kualitatif. Yogyakarta: Ar-Ruzz Media, 2012.

Marcus Barth, Ephesians 1-3. Doubledy Anchor Bible, 1974.

Mestika Zed, Metode Penelitian Kepustakaan. Jakarta: Penerbit Obor Indonesia, 2004.

Natalie Sproull, Handbook of Research Methods: A Guide for Prakticioners and Students in the Social Sciences. Metuchen: The Scarecrow Pres, 1988.

Richard M. Daulay, Mengenal Gereja Metodist Indonesia. Jakarta: BPK Gunung Mulia 2004.

Robert K. Yin, Case Study Research: Design and Methods. Second Edition. Thousand Oaks: SAGE Publications, 1994.

Stephano Ambesa, Bahasa Yunani Jakarta: Departemen Pendidikan Gereja Bethel Indonesia, 2006), 49.

Sudarwan Danim, Menjadi Peneliti Kualitatif (Bandung: Pustaka Setia, 2002), 105.

Sugiyono, Metodologi Penelitian Manajeman (Jakarta: ALFABETA, 2015), 24.

Suharsimi Arikunto, Prosedur Penelitian: Suatu pendekatan Praktek (Jakarta: Rineka Cipta, 1993), 90. 